Syntax Literate: Jurnal Ilmiah Indonesia p-ISSN: 2541-0849

e-ISSN: 2548-1398

Vol. 5, No. 11, November 2020

\title{
FAKTOR-FAKTOR PENUNJANG TERKENDALINYA KADAR HEMOGLOBIN TARGET PADA PASIEN HEMODIALISIA DENGAN TERAPI ERYTROPOIETIN
}

\author{
Nurhasanah dan Hesty Utami \\ Universitas Pancasila Jakarta, Jawa Barat, Indonesia \\ Email: yukeukenurhasanah@gmail.com dan h.ramadaniati@graduate.curtin.edu.au
}

\begin{abstract}
This study used a prospective study of chronic renal failure patients who performed hemodialysis in the outpatient room of the Usada Insani Hospital Tangerang during 2017, with a population of 217 people. The research instrument was derived from primary data from laboratory tests of hemoglobin levels at the beginning of each month or after 4 weeks of erythropoietin administration. Secondary data using medical record data collection and data collection formshemodialysis patients. The dependent variable hemoglobin levels collected data from the average $\mathrm{Hb}$ with at least 3 points and the independent was age, gender, length of hemodialysis and supplementary drugs that affect $\mathrm{Hb}$ production. These five independent variables are assumed to affect the dependent variable. The statistical analysis to be used is descriptive statistics and the Spearman test, s rho correlation. The results showed sig age 0.882>0.05, sig long hemodialysis 0.819>0.05, sig supplement 0.24>0.05 which has the meaning of static data processing test i.e. no relationship between age, length of hemoglobin $(\mathrm{Hb})$ with hemoglobin $(\mathrm{Hb})$ value. Based on the results of the study in the hemodialysis room at Usada Insani Tangerang Hospital, all patients with chronic kidney disease experienced a decrease in $\mathrm{Hb}$.
\end{abstract}

Keywords: Effectiveness; Hemoglobin Levels; Hemoglobin Levels (Hb)

\begin{abstract}
Abstrak
Tujuan dalam penelitian ini adalah melihat hubungan antara usia, jenis kelamin, lama menjalani hemodialisa, obat-obatan dengan kadar hemoglobin pada pasien yang menjalankan hemodialisa. Penelitian ini menggunakan studi prospektif pada pasien gagal ginjal kronik yang melakukan tindakan hemodialisa di ruang rawat jalan Rumah Sakit Usada Insani Tangerang selama tahun 2017, dengan jumlah populasi 217 orang. Instrumen penelitian berasal dari data primer hasil laboratorium pemeriksaan kadar hemoglobin setiap awal bulan atau setelah 4 minggu pemberian eritropoietin. Data sekunder menggunakan pengambilan data rekam medik dan formulir pengumpulan data pasien hemodialisa. Variabel dependen kadar hemoglobin mengambilan data dari $\mathrm{Hb}$ rata-rata dengan pengambilan minimal 3 titik dan independen adalah usia, jenis kelamin, lama hemodialisa dan obat-obat suplemen yang mempengaruhi produksi $\mathrm{Hb}$. Kelima variabel independen ini diasumsikan mempengaruhi variabel dependen. Analisis statistik yang digunakan adalah statistik deskriptif dan uji Spearmans rho correlation. Hasil penelitian menunjukkan sig usia $0.882>0.05$, sig lama hemodialisa $0.819>0.05$, sig suplemen $0.24>0.05$ yang
\end{abstract}


mempunyai arti secara uji pengolahan data statistik yaitu tidak ada hubungan antara usia, lama hemodialisa dan suplemen, Sehingga dapat disimpulkan bahwa tidak adanya hubungan antara usia, jenis kelamin, lama menjalani hemodialisa dan suplemen yang mempengaruhi target Hemoglobin dengan nilai hemoglobin. Berdasarkan hasil penelitian di ruangan hemodialisis di RS Usada Insani Tangerang didapatkan semua pasien penyakit ginjal kronik mengalami penurunan $\mathrm{Hb}$.

Kata kunci: Efektivitas; Hemodialisa; Kadar hemoglobin (Hb)

\section{Pendahuluan}

Penyakit ginjal kronik adalah penurunan faal ginjal yang menahun, yang umumnya tidak reversible dan cukup lanjut Penyakit ginjal kronik merupakan suatu proses yang patologis dengan etiologi yang beragam mengakibatkan penurunan fungsi ginjal yang progresif dan pada umumnya akan berakhir dengan gagal ginjal. Penyakit gagal ginjal ditandai dengan penurunan fungsi ginjal yang irreversible dengan waktu > 3 bulan disertai dengan penurunan laju filtrasi glomerulus (LFG) $<60 \mathrm{ml} /$ menit / $1.72 \mathrm{~m}^{2}$. Pada keadaan tertentu memerlukan terapi tindakan hemodialisa (Silviani, Dwianasari, \& Soedirman, 2010).

Berdasarkan data dari Perhimpunan Nefrologi Indonesia (Pernefri), yang menyatakan bahwa pada tahun 2015 di Indonesia terdapat 70.000 penderita gagal ginjal kronik. Jumlah tersebut diperkirakan akan meningkat sebesar $10 \%$ tiap tahunnya. Dari 70.000 penderita gagal ginjal kronik, terdapat sekitar 4000-5000 orang menjalani hemodialisa (Martono, 2015).

Akibat penyakit gagal ginjal kronik adalah cairan elektrolit dan sisa-sisa metabolisme yang tidak dapat dikeluarkan dari tubuh secara otomatis, sehingga pasien harus mendapatkan terapi pengganti ginjal (TPG) agar dapat terus menjalankan aktifitas. Terapi pengganti ginjal ada 3 yaitu: 1. hemodialisis, pada pasien yang melakukan hemodialisa agar dapat menurunkan kadar ureum dan kreatinin menjadi normal kembali harus dilakukan secara rutin satu sampai dua kali perminggu untuk mempertahankan kelangsungan hidup pasien, 2. peritoneal dialysis dan 3. transplantasi ginjal (Nurani \& Mariyanti, 2013).

Mayoritas pasien gagal ginjal kronik seringkali mengalami anemia. Hal ini disebabkan oleh kekurangan produksi erithropoietin yang dihasilkan oleh ginjal. Menurut Persatuan Nephrologi Indonesia ((PERNEFRI) P.N., 2011), pasien gagal ginjal kronik dinyatakan mengalami anemia bila kadar hemoglobin $(\mathrm{Hb})<10 \mathrm{gr} / \mathrm{dl}$ dan hematocrit $\leq 30 \%$ (Hervinda, Novadian, \& Tjekyan, 2014). Selain kekurangan hormon eritropoietin. Anemia juga dapat disebabkan oleh kekurangan zat besi, asam folat, ferritin, vitamin B6, Vitamin B12 serta penyakit kronis lainnya. Penanganan anemia pada pasien gagal ginjal kronik yang menjalankan hemodialisa dapat dilakukan melalui pemberian transfusi darah dan penggunaan erythropoietin (Silviani et al., 2010), Penelitian oleh (Fiocchi et al., 2017) menunjukkan beberapa efek samping yang muncul setelah pemberian Darbepoetin alfa pada anjing penderita penyakit ginjal kronis. Efek samping paling banyak ditemukan adalah peningkatan tekanan darah sistolik. Dua puluh 
lima anjing yang diperiksa tekanan darahnya, 24 anjing mengalami peningkatan tekanan darah sistolik dan efek samping pada gastrointestinal yang berupa diare ditemukan pada 1 anjing.

Seorang apoteker dalam penanganan pasien gagal ginjal kronik memiliki peran terkait dengan pengaturan dosis dan cara pemberian erytropoietin. Hal ini menjadi perhatian apoteker karena sekitar $10 \%$ pasien yang diberikan erytropoietin akan mengalami hiporesponsive terhadap penggunaan erytropoietin. Respon pasien yang menjalani hemodialisa terhadap pemberian erithropoietin tergantung pada beratnya kegagalan ginjal (B.G katzung). Selain itu juga karena defisiensi zat besi, obat-obatan (ACE inhibitor, ARB, renin inhibitor) dengan dosis tinggi dan lamanya menjalankan hemodialisa (Hervinda et al., 2014). Penelitian lain menyatakan terapi anemia dengan epoetin alfa dosis 3000 IU paling banyak digunakan, selama 2 bulan penelitian terdapat 542 kali pemakaian dari total 662 kali pemakaian, dengan obat anemia tambahan yang paling banyak digunakan adalah asam folat. Interaksi obat potensial dengan epoetin yang paling banyak terjadi adalah Angiotensin II Receptor Blocker (ARB) (96\%) dengan signifikansi 3. Efek samping yang paling banyak terjadi adalah efek samping pada sistem kardiovaskuler yang terjadi pada 20 (40\%) pasien, berupa udem dan kenaikan tekanan darah, kategori efek samping masing-masingnya adalah probable (kemungkinan besar efek samping). Efek samping dengan kategori definite (pasti efek samping) terjadi pada satu orang pasien dengan gejala pusing setiap kali setelah penggunaan epoeti (Andayani, 2016)

Sepanjang penulis mengamati hasil penelitian sebelumnya yang juga meneliti kadar hemoglobin pada pasien hemodialisis, beberapa jurnal memaparkan terkait efek samping yang muncul setelah pemberian erythropoietin pada penderima anemia pasien hemodialisis. Namun sejauh ini belum ditemukan penelitian tentang faktor-faktor penunjang terkendalinya kadar hemoglobin target pada pasien hemodialisia dengan terapi erytropoietin, sehingga penulis tertarik melakukan penelitian tersebut.

Berdasarkan latar belakang yang dipaparkan diatas, penulis melakukan penelitian awal di RS Usada Insani Tangerang dimana ada sekitar 90\% dari 217 pasien gagal ginjal memiliki hasil laboratorium dengan kadar hemoglobin <10 gr/dl, sehingga dinyatakan mengalami anemia dan membutuhkan pemberian terapi erythropoietin. Dari hasil tersebut penulis tertarik untuk melakukan penelitian dengan melihat faktor-faktor yang menyebabkan penurunan kadar hemoglobin pada pasien yang melakukan hemodialisa setelah mendapatkan terapi EPO di ruang tindakan hemodialisis rutin di RS Usada Insani Tangerang. Diharapkan penelitian ini menjadi acuan dalam upaya pencegahan penurunan hemoglobin pada pasien pasca hemodialisa dengan memperhatikan fakto-faktor yang mempengaruhinya.

\section{Metode Penelitian}

Metode dalam penelitian ini menggunakan studi prospektif. Penelitian ini dilakukan pada pasien gagal ginjal kronik yang melakukan tindakan hemodialisa di rawat jalan Rumah Sakit Usada Insani Tangerang selama tahun 2017. Instrumen 
penelitian berasal dari data primer hasil laboratorium pemeriksaan kadar hemoglobin setiap awal bulan atau setelah 4 minggu pemberian eritropoietin. Data sekunder menggunakan pengambilan data rekam medik dan formulir pengumpulan data pasien hemodialisa. Variabel dalam penelitian ini terdiri dari variabel dependent dan independent. Variabel dependen dalam penelitian ini adalah kadar hemoglobin $(\mathrm{Hb})$. Pengambilan data dari $\mathrm{Hb}$ rata-rata dengan pengambilan minimal 3 titik. Variabel independent meliputi usia, jenis kelamin, lama hemodialisa, obat-obat suplemen yang mempengaruhi produksi $\mathrm{Hb}$ dan penyakit penyerta. Kelima variabel independen ini diasumsikan mempengaruhi variabel dependen. Analisis statistik yang akan digunakan adalah statistik deskriptif dan uji Spearman,s rho correlation.

\section{Hasil dan Pembahasan}

\section{A. Data Sosiodemografi}

Data sosiodemografi pasien hemodialisa yang digunakan sebagai sampel diperoleh dari status rekam medis dan pengisian biodata yang dilakukan oleh pasien itu sendiri. Data sosiodemografi meliputi usia, jenis kelamin, lama menjalani hemodialisa, suplemen yang mempengaruhi produksi $\mathrm{Hb}$ yang digunakan dan penyakit penyerta. Data sosiodemografi pasien hemodialisa dapat dilihat pada tabel 1

\section{Tabel 1}

Karakteristik Sosio-Demografi Pasien Hemodialisa

\begin{tabular}{lll}
\hline Karakteristik pasien Hemodialisa & Jumlah & Persentase \% \\
\hline Berdasarkan jenis kelamin & & \\
Laki-laki & $\mathbf{1 1 3}$ & $\mathbf{5 6 , 5 0 \%}$ \\
Perempuan & 87 & $43,50 \%$ \\
Berdasarkan usia & & \\
17-25 tahun & 3 & $1,50 \%$ \\
26-35 tahun & 12 & $6 \%$ \\
36-45 tahun & 40 & $20 \%$ \\
46-55 tahun & $\mathbf{6 9}$ & $\mathbf{3 4 , 5 0 \%}$ \\
56-65 tahun & $\mathbf{5 9}$ & $\mathbf{2 9 , 5 0 \%}$ \\
$>$ 65 tahun & 17 & $8,50 \%$ \\
\hline Berdasarkan lama menjalani Hemodialisa & & \\
1-24 bulan & $\mathbf{1 5 2}$ & $\mathbf{7 6 \%}$ \\
25-48bulan & 37 & $18,50 \%$ \\
$>48$ bulan & 11 & $5,50 \%$ \\
\hline Berdasarkan jumlah obat-obatan & & \\
1 obat & $\mathbf{9 1}$ & $\mathbf{4 5 , 5 0 \%}$ \\
2 obat & 40 & $20 \%$ \\
3 obat & 39 & $19,50 \%$ \\
4 obat & 25 & $12,50 \%$ \\
5 obat & 3 & $1,50 \%$ \\
6 obat & 2 & $1 \%$ \\
Berdasarkan kadar HD & & \\
Target Hemoglobin (Hb) tercapai & 12 & $6 \%$ \\
Target Hemoglobin (Hb) tidaktercapai & $\mathbf{1 8 8}$ & $\mathbf{9 4 \%}$ \\
\hline
\end{tabular}




\begin{tabular}{lll}
\hline Berdasarkan Penyakit Penyerta & & \\
1 Penyakit & $\mathbf{1 3 7}$ & $\mathbf{6 8 , 5 \%}$ \\
2 Penyakit & $\mathbf{5 2}$ & $\mathbf{2 6 \%}$ \\
3 Penyakit & $\mathbf{1 0}$ & $\mathbf{5 \%}$ \\
4 Penyakit & $\mathbf{1}$ & $\mathbf{0 , 5 \%}$ \\
\hline
\end{tabular}

Berdasarkan data sosiodemografi yang disajikan pada tabel 1, diketahui bahwa berdasarkan jenis kelamin kebanyakan berjenis kelamin laki-laki yaitu 113 orang atau $56,5 \%$ dan 87 orang perempuan atau $43,5 \%$ dari total populasi pasien hemodialisa. Berdasarkan hasil riset kesehatan dasar (Rikesdas) pada tahun 2015 menyatakan bahwa jumlah penderita laki-laki lebih tinggi dari perempuan 0,2\% yang menjalani hemodialisa (Kementrian RI, 2017). Besarnya angka kejadian gagal ginjal kronis yang dialami laki-laki karena pengaruh perbedaan hormon reproduksi dan gaya hidup yang kurang baik seperti mengkonsumsi alkohol, garam dan rokok yang merupakan faktor yang dapat menyebabkan kerusakan ginjal.

Pasien hemodialisa di RS Usada Insani Tangerang berdasarkan usia dimana kategori lansia awal (46-55 tahun) 69 sampel (34,9\%) dan lansia akhir (56-65 tahun) sebanyak 59 sampel $(29,5 \%)$ dari total populasi sampel pasien hemodialisa. Sedangkan untuk kategori usia yang paling kecil adalah remaja akhir (17-25 tahun) dengan total pasien sebanyak 3 orang $(1,5 \%)$ sedangkan usia masa manula (>65tahun) 17 sampel $(8,5 \%)$. Hasil ini sesuai dengan pernyataan bahwa prevalensi PGK akan meningkat dengan seiring bertambahnya umur (Indonesia Renal Registry (IRR), 2015). Juga sejalan dengan hasil penelitian di RS Bethesda bahwa terjadi peningkatan jumlah pasien seiring bertambahnya umur (Fauziah, Wahyono, \& Budiarti, 2015).

Lebih lanjut dijelaskan bahwa semakin bertambahnya usia, maka organ ginjal mengalami penurunan massa ginjal sebagai akibat kehilangan beberapa nefron sehingga terjadi penurunan laju filtrat glomerulus. Penurunan laju filtrasi glomerulus (akibat tidak berfungsinya glomeruli) berdampak pada klirens kreatinin akan menurun dan kadar kreatinin serum akan meningkat. Kemudian akan berlanjut dengan kegagalan ginjal secara progresif. lansia terjadi penurunan jumlah nefron sebesar 5-7\% setiap dekade mulai usia 25 tahun (Martono, 2015).

Berbeda dengan hasil penelitian (Hervinda et al., 2014) bahwa pasien yang melakukan hemodialisa lebih banyak perempuan dibandingkan dengan jenis kelamin laki-laki (53\% dan 47\%). Jenis kelamin bukanlah merupakan faktor resiko utama terjadinya penyakit ginjal kronik karena hal ini juga berhubungan dengan ras, faktor genetik dan lingkungan. Untuk jenis kelamin tidak menjadi faktor utama pasien mengalami gagal ginjal stage $\mathrm{V}$ dan hemodilisa akan tetapi berdasarkan sampel pada lokasi penelitian (Neng Herawati, 2009).

Berdasarkan tabel 1, lama menjalani hemodialisa dengan waktu 1 - 24 bulan yaitu sebanyak 156 orang atau (76\%), 25-48 bulan sebanyak 37 sampel (18,5\%), >48 bulan sebanyak 11 sampel (5,5\%). Prevalensi antara pasien hemodialisa dengan obatobatan yang digunakan terbanyak pasien konsumsi dengan 1 jenis obat yaitu 91 
sampel atau 45,5\%, 2 jenis obat dengan 40 sampel (20\%), 3 jenis obat dengan 39 sampel (19,5\%), 4 jenis obat dengan 25 sampel (12,5\%), 5 jenis obat 3 sampel $(1,5 \%)$ dan 6 jenis obat 2 sampel atau $(1 \%)$.

Pada tabel 1 pun kita dapati bahwa pasien hemodialisa selain menderita gagal ginjal kronik stage $\mathrm{V}$, juga adanya penyakit penyerta yang diderita oleh pasien hemodialisa tersebut. Dari data pada tabel 1 menggambarkan 1 penyakit penyerta sebanyak 137 orang atau (68,5\%), 2 penyakit penyerta 52 sampel atau (26\%), 3 penyakit penyerta 10 orang atau $(5 \%)$ dan 4 penyakit penyerta 1 orang $(0,5 \%)$. Untuk penyakit penyerta yang diderita oleh pasien hemodialisa adalah hipertensi, diabetes mellitus, jantung, kolesterol dan asam urat, dan penyakit tunggal terbanyak yaitu hipertensi.

Data sumber Indonesia renal registry (IRR) tahun 2015 penyatakan bahwa penyebab penyakit ginjal kronik terbesar adalah diabetes mellitus. Di Indonesia sampai dengan tahun 2000 penyebab terbanyak adalah glomerulonephritis, namun beberapa tahun terakhir penyebab terbanyak hipertensi berdasarkan data IRR. Namaun belum dapat dipastikan apakah memang hipertensi merupakan penyebab PGK atau hipertensi akibat penyakit ginjal tahap akhir karena data IRR didapatkan dari pasien hemodialisa yang sebagian merupakan pasien dengan penyakit ginjal tahap akhir (Kementrian RI, 2017).

2. Hubungan antara Usia, Jenis Kelamin, Lama Menjalani Hemodialisa, Obat-Obatan dengan Kadar Hemoglobin ( $\mathrm{Hb})$.

Penelitian ini bertujuan untuk mengetahui hubungan antara variabel independent (jenis kelamin, usia, lama menjalani hemodialisa dan obat-obat suplemen yang mempengaruhi target Hemoglobin $(\mathrm{Hb})$ ) dengan variabel dependent yaitu nilai kadar hemoglobin $(\mathrm{Hb})$. Diharapkan dengan melakukan uji statistik berupa uji hubungan/korelasi ini dapat diketahui faktor-faktor yang paling dominan berhubungan dengan terjadinya penyakit ginjal kronik dengan hemodialisa. Sebelum melakukan uji statistikini, maka perlu dilakukan uji pendahuluan terlebih dahulu diantaranya uji normalitas. Uji normalitas dilakukan untuk menentukan uji statistik selanjunya. Kaidah keputusan hasil uji normalitas adalah apabila data tersebut berdistribusi normal maka dilanjutkan dengan uji statistik parametrik. Sebaliknya apabila hasil uji normalitas data tidak berdistribusi normal, maka uji selanjutnya menggunakan uji nonparametrik. Hasil uji normalitas diperoleh bahwa data tidak terdistribusi normal, sehingga selanjutnay dilakukan uji nonparametrik.

Data yang digunakan dalam penelitian ini berskala ordinal untuk usia, lama menjalani hemodialisa, suplemen yang meningkatkan kadar hemoglobin $(\mathrm{Hb})$ dan target kadar hemoglobin $(\mathrm{Hb})$. Oleh karena itu uji statistik yang digunakan adalah analisa correlate bivariate dengan menggunakan uji Spearman,s rho correlation. Hasil uji Spearman,s rho correlation disajikan pada tabel 2. 


Tabel 2
Hasil korelasi antara usia, lama menjalani hemodialisa,
dengan kadar hemoglobin (Hb)

Hasil yang disajikan pada tabel 2 dapat ditarik kesimpulan bahwa hasil uji Spearman,s rho correlation antara usia, lama menjalani hemodialisa, suplemen yang mempengaruhi target hemoglobin $(\mathrm{Hb})$ dengan target kadar hemoglobin $(\mathrm{Hb})$ diperoleh nilai sig $>0,05$. Ini artinya tidak terdapat hubungan yang bermakna antara usia, lama menjalani hemodialisa, Suplemen yang mempengaruhi target hemoglobin $(\mathrm{Hb})$ dengan target kadar hemoglobin $(\mathrm{Hb})$. Namun bila dilihat secara teori, akan terlihat adanya hubungan antara usia, jenis kelamin, lama menjalani hemodialisa, seplemen dan penyakit dengan target kadar hemoglobin $(\mathrm{Hb})$ melalui perbandingan data-data variabel-variabel tersebut.

Untuk jenis kelamin, tidak dapat dilakukan uji Spearman,s rho correlation namun hubungan antara jenis kelamin dengan kadar hemoglobin $(\mathrm{Hb})$ dapat dilihat secara deskriptif seperti yang disajikan pada tabel 3

Tabel 3

Hasil distribusi jenis kelamin dengan kadar Hemoglobin (Hb)

\begin{tabular}{lcc}
\hline \multicolumn{1}{c}{\begin{tabular}{c} 
variabel independent \\
\multicolumn{1}{c}{ (jenis kelamin) }
\end{tabular}} & \multicolumn{2}{c}{ Nilai target Hemoglobin $(\mathrm{Hb})$} \\
& $\begin{array}{c}\text { Tidak tercapai } \\
<10 \mathrm{~g} / \mathrm{dl}\end{array}$ & $\begin{array}{c}\text { Tercapai } \\
10-13 \mathrm{~g} / \mathrm{dl}\end{array}$ \\
\hline laki-laki & 104 & 10 \\
Perempuan & 84 & 2 \\
\hline
\end{tabular}

Berdasarkan hasil pada tabel 3, terlihat bahwa jenis kelamin tidak berhubungan dengan rendahnya kadar hemoglobin $(\mathrm{Hb})$. Pasien laki-laki lebih banyak dibanding pasien perempuan. Hasil ini sesuai dengan penelitian (Setiyowati \& Hastuti, 2014) bahwa pasien paling banyak untuk menjalani hemodialisa adalah laki-laki (Setyowati,2014). Juga sesuai dengan pendapat yang disampaikan (United States Renal Data System/ USRDS). yang menjelaskan bahwa jenis kelamin laki laki sangat beresiko terjadinya gangguan fungsi ginjal, hal ini disebabkan struktur dan anatomi saluran perkemihan yang panjang dan juga aliran urine yang lama, sehingga beresiko menempelnya sampah atau sisa metabolisme pada saluran kemih. Kondisi tersebut memicu terjadinya obstruksi pada salurah kemih sehingga terjadi refluks fan resiko infeksi pada ginjal. Hal tersebut memungkinkan resiko tinggi terjadinya pengendapan zat-zat yang terkandung dalam urin lebih banyak dibanding perempuan. Pengendapan dengan proses yang lama dapat membentuk batu baik pada saluran 
kemih maupun pada ginjal. Bila gangguan fungsi ginjal tersebut berlangsungsecara progresif dapat menimbulkan gagal ginjal pada tahap terminal (Martono, 2015).

Distribusi usia penderita penyakit ginjal kronis dengan kadar Hemoglobin $(\mathrm{Hb})$ disajikan pada tabel 4 .

Tabel 4

Hasil distribusi usia dengan kadar Hemoglobin (Hb)

\begin{tabular}{|c|c|c|}
\hline \multirow[b]{2}{*}{$\begin{array}{c}\text { variabel independent } \\
\text { (Usia) }\end{array}$} & \multicolumn{2}{|c|}{ Nilai target Hemoglobin (Hb) } \\
\hline & $\begin{array}{l}\text { Tidak tercapai } \\
<10 \mathrm{~g} / \mathrm{dL}\end{array}$ & $\begin{array}{r}\text { Tercapai } \\
10-13 \mathrm{~g} / \mathrm{dL}\end{array}$ \\
\hline $17-25$ & 3 & 0 \\
\hline $26-35$ & 12 & 0 \\
\hline $36-45$ & 38 & 2 \\
\hline $46-55$ & 64 & 5 \\
\hline $56-65$ & 56 & 3 \\
\hline$>65$ & 16 & 1 \\
\hline
\end{tabular}

Berdasarkan hasil yang disajikan pada tabel 4,terlihat bahwa usia tidak berhubungan dengan rendahnya kadar hemoglobin ( $\mathrm{Hb}$ ). Hubungan secara teoritis, kondisi fisik semakin tua maka untuk faktor fisiologis akan semakin menurun sehingga pengendalian kadar hemoglobin $(\mathrm{Hb})$ menjadi lebih sulit. Akan tetapi pada pasien penyakit gagal ginjal kronik yang menjalani hemodialisa hal ini berlaku untuk semua usia.

Pada tabel 4 diperoleh hasil data perbandingan usia dengan kadar hemoglobin $(\mathrm{Hb})$. Data terbanyak pada usia masa lansia awal dan lansia akhir dengan kadar hemoglobin antara 7-10g/dL. Pada usia remaja akhir (7-25 tahun) juga terdapat kadar hemoglobin $(\mathrm{Hb})$ antara $7-10 \mathrm{~g} / \mathrm{dL}$ serta terdapat 1 sampel dengan nilai hemoglobin $<7 \mathrm{~g} / \mathrm{dL}$ ini. Hal ini dapt disimpulkan tidak adanya hubungan antara usia dengan nilai hemoglobin $(\mathrm{Hb})$. Data mengenai penyakit ginjal diperoleh dari hasil Riset Kesehatan Dasar (Rikesdas) Indonesia Renal Regystri (IRR) bahwa umur $>15$ tahun terdiagnosa sebesar 0.2\% (Kementrian Kesehatan Repunlik Indonesia., 2014).

Untuk perbandingan data antara lama menjalani hemodialisa dengan nilai hemoglobin $(\mathrm{Hb})$ dapat dilihat pada tabel 5 .

\section{Tabel 5}

Hasil data perbandingan lama menjalani Hemodialisa dengan kadar Hemoglobin (Hb)

\begin{tabular}{ccc}
\hline $\begin{array}{c}\text { variabel independent } \\
\text { (Lama menjalani } \\
\text { hemodialisa) }\end{array}$ & $\begin{array}{c}\text { Nilai target Hemoglobin }(\mathrm{Hb}) \\
\text { Tidak tercapai } \\
<10 \mathrm{~g} / \mathrm{dL}\end{array}$ & $\begin{array}{c}\text { Tercapai } \\
10-13 \mathrm{~g} / \mathrm{dL}\end{array}$ \\
\hline 1-24 bulan & 144 & 8 \\
$25-48$ bulan & 34 & 4 \\
$>48$ bulan & 9 & 1 \\
\hline
\end{tabular}


Lamanya pasien menjalani hemodialisa terbanyak yaitu 1-24 bulan dengan nilai hemoglobin $(\mathrm{Hb})<7 \mathrm{~g} / \mathrm{dL}$ sebanyak 36 sampel, nilai kadar hemoglobin 7$10 \mathrm{~g} / \mathrm{dL}$ sebanyak 108 sampel dan nilai hemoglobin $(\mathrm{Hb})>10 \mathrm{~g} / \mathrm{dL}$ sebanyak 8 sampel. Dari data perbandingan ini terlihat bahwa tidak adanya hubungan lama menjalani hemodialisa dengan nilai hemoglobin $(\mathrm{Hb})$. Penelitian ini sesuai (Silviani et al., 2010). menyatakan bahwa tidak terdapat hubungan antara lama hemodilisis dengan status hemoglobin, dikarenakan banyak beberapa faktor-faktor yang mempengaruhi nilai status hemoglobin (Silviani et al., 2010).

Pada pasien penyakit ginjal kronik yang menjalani hemodialisa seringkali mendapatkan tambahan suplemen vitamin berupa folic acid, Fe+vitamin, vitamin B6 dan vitamin B12. Hal ini dimaksudkan untuk meningkatkan kadar hemoglobin $(\mathrm{Hb})$ dalam darah sebagaimana disajikan pada tabel 6 .

Tabel 6

Hasil distribusi penggunaan suplemen dengan kadar hemoglobin (Hb)

\begin{tabular}{|c|c|c|c|}
\hline \multirow{2}{*}{$\begin{array}{c}\text { Kombi } \\
\text { nasi suplemen }\end{array}$} & \multirow[b]{2}{*}{ Jenis suplemen } & \multicolumn{2}{|c|}{ Jumlah pemberian suplemen } \\
\hline & & $\begin{array}{c}<10 \mathrm{~g} / \mathrm{dL} \text { (tidak } \\
\text { tercapai) }\end{array}$ & $\begin{array}{l}>10-13 \mathrm{~g} / \mathrm{dL} \\
\text { (Tercapai) }\end{array}$ \\
\hline \multirow{5}{*}{ Tunggal } & Folic acid $1 \mathrm{mg}$ & 26 & 1 \\
\hline & Hemobion & 18 & 3 \\
\hline & Sangobion & 17 & 6 \\
\hline & Vitamin B6 10mg & 59 & 5 \\
\hline & Vitamin B12 50mg & 5 & 0 \\
\hline \multirow{4}{*}{$\begin{array}{l}\text { kombinasi } 2 \\
\text { obat suplemen }\end{array}$} & Folic acid, Vitamin B6 & 10 & 1 \\
\hline & Folic acid, vitamin B12 & 19 & 2 \\
\hline & Sangobion, Hemafort & 3 & 0 \\
\hline & Sangobion, Vitamin B6 & 5 & 0 \\
\hline $\begin{array}{l}\text { kombinasi } 3 \\
\text { obat suplemen }\end{array}$ & $\begin{array}{l}\text { Sangobion, folic acid, } \\
\text { vitamin B6 }\end{array}$ & 2 & 0 \\
\hline
\end{tabular}

Hasil pada tabel 6 terlihat bahwa penggunaan suplemen baik tunggal maupun kombinasi belum efektif dalam mencapai target kadar hemoglobin ( $\mathrm{Hb}$ ). Pasien penyakit gagal ginjal kronik dengan melakukan hemodialisis akan dberikan asam folat. Asam folat berperan dalam pemulihan dan pemeliharaan hematopoiesis normal (H.j Deglin AHV, 2005). Pasien yang menderita gagal ginjal kronik mengalami kerusakan pada ginjal yang mengindikasikan bahwa ginjal tidak mampu menjalankan fungsinya dengan baik sehingga erytropoietin tidak akan diproduksi (Schiffl \& Lang, 2006).

Kadar nilai hemoglobin normal untuk perempuan $10 \mathrm{gr} / \mathrm{dL}$ dan untuk laki-laki $14 \mathrm{~g} / \mathrm{dL}$, anemia dapat terjadi bila kadar hemoglobin $(\mathrm{Hb})$ mengalami penunrunan di 
bawah batas normal dikarenakan tubuh kita tidak membuat sel darah merah sesuai dengan dibutuhkan oleh tubuh. Proses ini membutuhkan vitamin B12 dan asam folat. Eruythropoietin adalah hormone yang merangsang pembuatan sel darah merah dan diproduksi oleh ginjal (Neng Herawati, 2009).

Hasil target hemoglobin $(\mathrm{Hb})$ dengan menggunakan obat suplemen terbanyak bila dilihat pada tabel 6 adalah suplemen folic acid. Namun demikian pemberian suplemen folic acid tidak menunjukan peningkatan target kadar hemoglobin ke nilai normal. Hasil target hemoglobin setelah diberikan suplemen folic acid masih dibawah normal yaitu $<10 \mathrm{~g} / \mathrm{dL}$.

Meski demikian, pasien gagal ginjal kronik yang menjalani hemodialisa tetap menerima konsumsi suplemen untuk mengatasi anemia yang dideritanya. Data dari tabel 6 pun memperlihatkan adanya data perbandingan antara suplemen dengan nilai kadar hemoglobin( $\mathrm{Hb})$. Data penggunaan suplemen dengan nilai hemoglobin $<10 \mathrm{~g} / \mathrm{dL}$ (tidak tercapai) lebih banyak dibandingkan dengan data hemoglobin $>10 \mathrm{~g} / \mathrm{dL}$ (tercapai).

Hasil perbandingan penggunaan obat-obatan suplemen dengan nilai kadar hemoglobin $(\mathrm{Hb})$ dapat asumsikan bahwa penggunaan 1 suplemen yaitu asam folat dengan hasil tertinggi pengukuran kadar hemoglobin menunjukkan adanya peningkatan kadar hemoglobin setelah dilakukan terapi dengan asam folat terhadap pasien dengan persentase sebanyak 85\% dengan pemberian 27 kali. Apabila dilihat dari persentasenya maka dapat dikatakan bahwa asam folat memberikan pengaruh terhadap kadar hemoglobin dari pasien (Alvionita, Ayu, \& Masruhim, 2016).

Berdasarkan ketentuan nilai normal kadar hemoglobin apabila dilihat pada tabel 6 nilai kadar hemoglobin yang didapatkan pada suplemen tidak menjadikan kadar hemoglobin pasien menjadi normal. Hal ini dapat dilihat dari kadar rata-rata hemoglobin pasien setelah terapi yaitu $<10 \mathrm{~g} / \mathrm{dL}$ yang mana kadar ini masih di bawah batas kadar normal hemoglobin.

Pasien hemodialisa pada tabel 6 menunjukan bahwa penggunaan obat-obatan tanpa adanya suplemen penambah darah menunjukan penurunan target hemoglobin (Hb) semua pasien dengan nilai target hemoglobin $<10 \mathrm{~g} / \mathrm{dL}$. dari jumlah sampel hanya di dapatkan nilai target hemoglobin $(\mathrm{Hb})>10-13 \mathrm{~g} / \mathrm{dL}$ dengan sampel sejumlah 6 sampel pada penggunaan amlodipine (tunggal), dan 2 sampel pada penggunaan amlodipine dan paracetamol. Semakin banyak pasien hemodialisa menggunakan jumlah obat yang dikonsumsi pada tabel 6 bahwa target nilai kadar hemoglobin $(\mathrm{Hb})<10 \mathrm{~g} / \mathrm{dL}$.

Ketersediaan obat erytropoietin dipergunakan untuk terapi pasien yang mengalami anemia pada pasien gagal ginjal kronik, selain pemberian erytropoietin diberikan juga suplemen oral seperti folic acid, Vitamin B6 dan Vitamin B12 dipergunakan untuk memperbaiki kadar hemoglobin $(\mathrm{Hb})$. Pada kondisi pasien normal terdapat suatu hubungan terbalik antara kadarhemoglobin $(\mathrm{Hb})$ dengan kadar erytropoietin dikecualikan pada pasien gagal ginjal kronik karena ginjal sudah tidak optimal dalam memproduksi erotropoietin sehingga terjadinya anemia. Hal ini dapat 
dilihat tidak adanya efektivitas pemberian erytropoietin terhadap kadar hemoglobin (Hb) (Katzung, 2001).

Analisa hubungan antara perbandingan jumlah penyakit penyerta yang diderita pasien gagal ginjal kronis dengan nilai kadar hemoglobin $(\mathrm{Hb})$ terlihat pada tabel 7.

Tabel 7

Hasil perbandingan lama Hemodialisa dengan kadar Hemoglobin (Hb)

\begin{tabular}{ccc}
\hline $\begin{array}{c}\text { variabel independent } \\
\text { (Penyakit penyerta) }\end{array}$ & $\begin{array}{c}\text { Nilai target Hemoglobin }(\mathrm{Hb}) \\
\text { Tidak tercapai } \\
<10 \mathrm{~g} / \mathrm{dL}\end{array}$ & $\begin{array}{c}\text { Tercapai } \\
10-13 \mathrm{~g} / \mathrm{dL}\end{array}$ \\
\hline 1 Penyakit & 129 & 8 \\
2 Penyakit & 46 & 4 \\
3 Penyakit & 9 & 1 \\
4 Penyakit & 1 & 0 \\
\hline
\end{tabular}

Berdasarkan data pada tabel 7, bahwa 1 penyakit merupakan jumlah pasien terbanyak dengan nilai hemoglobin $<7 \mathrm{~g} / \mathrm{dL}$ sebanyak 29 sampel, nilai hemoglobin $(\mathrm{Hb})$ antara 7-9g/dL sebanyak 100 sampel dan nilai hemoglobin $>10 \mathrm{~g} / \mathrm{dL}$ sebanyak 8 sampel. Jumlah penyakit penyerta terbanyak yaitu 4 penyakit penyerta dengan nilai kadar hemoglobin $(\mathrm{Hb})<7 \mathrm{~g} / \mathrm{dL}$ sebanyak 1 sampel. Dari data tersebut bahwa semakin banyaknya penyakit penyerta dapat memperlihatkan nilai hemoglobin $(\mathrm{Hb})$ yang rendah.

\section{Kesimpulan}

Pasien hemodialisa yang mencapai target hemoglobin $(\mathrm{Hb})$ sebanyak 12 sampel dengan persentase $6 \%$ dibandingkan dengan pasien tidak mencapai target 188 sampel dengan persentase $94 \%$. Faktor-faktor usia, jenis kelamin, lama hemodialisa, obatobatan serta penyakit penyerta tidak mempunyai hubungan atau korelasi dengan nilai hemoglobin $(\mathrm{Hb})$ pasien yang melakukan hemodialisa. Pemberian eritropoietin kepada pasien gagal ginjal kronik dengan hemodialisa belum memberikan efektivitas pencapaian kadar hemoglobin $(\mathrm{Hb})$ normal $>10-13 \mathrm{~g} / \mathrm{dL}$. 


\section{BIBLIOGRAFI}

(PERNEFRI) P.N. (2011). Konsensus Manajemen Anemia Pada Pasien Gagal Ginjal Kronik. https://kpcdi.org/2016/05/19/managemen-anemia-pada-pasiengagal-ginjal-kronik/

Alvionita, Alvionita, Ayu, Welinda Dyah, \& Masruhim, Muhammad Amir. (2016). Pengaruh Penggunaan Asam Folat terhadap Kadar Hemoglobin Pasien Penyakit Ginjal Kronik yang Menjalani Hemodialisis di RSUD Abdul Wahab Sjahranie. Journal of Tropical Pharmacy and Chemistry, 3(3), 179-184.

Andayani, Ramadhela Anindya dan Tri Murti. (2016). Kajian Efek Samping dan Interaksi penggunaan Epoetin sebagai Terapi Pasien Gagal Ginjal Kronis dengan Anemia. Skripsi. Universitas Gajah Mada.

Fauziah, Fauziah, Wahyono, Djoko, \& Budiarti, L. Endang. (2015). Cost of illness dari chronic kidney disease dengan tindakan hemodialisis. Jurnal Manajemen Dan Pelayanan Farmasi (Journal of Management and Pharmacy Practice), 5(3), 143151.

Fiocchi, E. H., Cowgill, Larry D., Brown, D. C., Markovich, J. E., Tucker, S., Labato, M. A., \& Callan, M. B. (2017). The use of Darbepoetin to stimulate erythropoiesis in the treatment of Anemia of chronic kidney disease in dogs. Journal of Veterinary Internal Medicine, 31(2), 476-485.

H.j Deglin AHV. (2005). Pedoman Obat Untuk Perawat. Jakarta: Penerbit Buku Kedokteran EGC

Hervinda, Sundari, Novadian, Novadian, \& Tjekyan, R. M. Suryadi. (2014). Prevalensi dan Faktor Risiko Penyakit Ginjal Kronik di RSUP Dr. Mohammad Hoesin Palembang Tahun 2012. Majalah Kedokteran Sriwijaya, 46(4), 275-281.

Indonesia Renal Registry (IRR). (2015). 8th Report of Indonesia Renal Registry. Jakarta: Perhimpunan Nefrologi Indonesia (PERFERNI).

Katzung, B. G. (2001). Farmakologi Dasar dan Klinik: Obat Antijamur. Edisi, 5, 23-24.

Kementrian Kesehatan Repunlik Indonesia. (2014). Pusat Data dan Informasi Kesehatan Kementerian Indonesia.

Kementrian RI. (2017). Pusat Data dan Informasi Kementrian Kesehatan RI. ISSN 2442-, 1-12. Kemenkes RI.

Martono, Martono. (2015). Penurunan Resiko Henti Jantung Pada Asuhan Keperawatan Pasien Yang Dilakukan Hemodialisa Melalui Pengendalian Overload Cairan Kalium Serum. Interest: Jurnal Ilmu Kesehatan, 4(1).

Neng Herawati. (2009). Mengenal Anemia dan Peran Erithropoietin Bio Trends. 4(1), 
Faktor-Faktor Penunjang Terkendalinya Kadar Hemoglobin Target pada Pasien Hemodialisia dengan Terapi Erytropoietin

$35-9$.

Nurani, Vika Maris, \& Mariyanti, Sulis. (2013). Gambaran makna hidup pasien gagal ginjal kronik yang menjalani hemodialisa. Jurnal Psikologi Esa Unggul, 11(01), 127032.

Schiffl, Helmut, \& Lang, Susanne M. (2006). Folic acid deficiency modifies the haematopoietic response to recombinant human erythropoietin in maintenance dialysis patients. Nephrology Dialysis Transplantation, 21(1), 133-137.

Setiyowati, Andaru, \& Hastuti, Weni. (2014). Hubungan Tingkat Pengetahuan Dengan Kecemasan Pasien Hemodialisa Di Rumah Sakit PKU Muhammadiyah Surakarta. Profesi (Profesional Islam): Media Publikasi Penelitian, 11(01).

Setiyowati, Andaru, Hastuti, Weni, \& Surakarta, Kadipiro Banjarsari. (2014). Hubungan Tingkat Pengetahuan dengan kecemasan pasien. Profesi 11, 5-8.

Silviani, Dewi, Dwianasari, L., \& Soedirman, U. J. (2010). Hubungan Lama Periode Hemodialisis Dengan Status Albumin Penderita Gagal Ginjal Kronik Di Unit Hemodialisis RSUD. Prof. Dr. Margono Soekarjo Purwokerto Tahun, 5, 361-363. 